\title{
Radial jet drilling (RJD) laterals in fractured geothermal reservoirs
}

\section{Grandahl, M.; Medetbekova, Maiya; Salimzadeh, Saeed; Nick, H. M.}

\section{Published in:}

Proceedings of the 80th EAGE Conference and Exhibition 2018

Link to article, DOI:

$10.3997 / 2214-4609.201801170$

Publication date:

2018

Document Version

Early version, also known as pre-print

Link back to DTU Orbit

Citation (APA):

Grandahl, M., Medetbekova, M., Salimzadeh, S., \& Nick, H. M. (2018). Radial jet drilling (RJD) laterals in fractured geothermal reservoirs. In Proceedings of the 80th EAGE Conference and Exhibition 2018 (pp. 25752579). European Association of Geoscientists and Engineers. https://doi.org/10.3997/2214-4609.201801170

\section{General rights}

Copyright and moral rights for the publications made accessible in the public portal are retained by the authors and/or other copyright owners and it is a condition of accessing publications that users recognise and abide by the legal requirements associated with these rights.

- Users may download and print one copy of any publication from the public portal for the purpose of private study or research.

- You may not further distribute the material or use it for any profit-making activity or commercial gain

- You may freely distribute the URL identifying the publication in the public portal 


\title{
Radial Jet Drilling (RJD) Laterals in Fractured Geothermal Reservoirs
}

\author{
Mark Lusty Grandahl, Maiya Medetbekova, Saeed Salimzadeh, Hamidreza M. Nick
}

The Danish Hydrocarbon Research and Technology Center

\begin{abstract}
The effect of RDJ laterals on the productivity of a naturally fractured geothermal system has been investigated in this study. A doublet system in a reservoir of $3 \times 3 \times 0.1 \mathrm{~km}$. with two sets of natural fractures has been the object for the study. The preliminary results show that the placement of the well in such a system has a significant impact on the productivity of such a system. And that RDJ's can be used to further improve the productivity of the system.
\end{abstract}

\section{Introduction}

The world's energy consumption has been constantly increasing, and the U.S. Energy Information Administration (EIA) predicts that by 2040 the energy consumption will have increased by approximately $28 \%$. According to their prediction the energy sources which will increase the most is natural gas and renewables. The known potential for geothermal energy is given by the Geothermal Energy Association to be between 3,675 (95\%) and 16,457 (5\%) MWe in the Western United States alone. If Enhanced Geothermal Systems are included in this, the potential will rise to somewhere between 345,100 (95\%) and 727,900 (5\%) MWe. The first geothermal power plant was built near Pisa in Italy in the early 1900's by an Italian scientist named Piero Ginori Conti. The power plant used steam to generate electricity. So, the thought of using the heat from the Earth to produce power goes back approximately 100 years.

This study will focus on the productivity of an Enhanced Geothermal System (EGS). EGS and normal geothermal systems has the same purpose, which is to produce heat from the subsurface by injecting a cold fluid and producing a hot fluid. EGS is used when the natural permeability of the reservoir cannot guarantee an economical flow rate. In that case the reservoir is artificially fractured to enhance the flow between injector and producer wells. This method of stimulation has its shortcomings including induced seismicity, and environmental issues due to little control on the induced fractures geometry. An alternative method of stimulation is to connect the injection and production wells to the natural fractures using small-diameter laterals created by jetted water.

Radial Jet Drilling (RJD) is an economically feasible well stimulation technique that uses the power of a jetting fluid to create lateral holes. The laterals can be extended to $100-200 \mathrm{~m}$ with a diameter size up to 2 inches, in 16 directions from the existing well shafts (Kamel, 2014; Buset, 2001). Observations from documented field cases show that implementation of RJD laterals in hydrocarbon fields increases production significantly.

In this research, the application of RJD laterals in enhancing the productivity of a low-permeability geothermal reservoir is studied. A fully coupled thermoporoelastic model for discrete fractures in a deformable medium has been utilized for running simulations (Salimzadeh et al. 2018a, b). The fractures are modelled as surfaces in the three-dimensional matrix. The coupled computational model consists of three separate but interacting sub-models: a mechanical deformation model, flow model and heat transfer model. To reduce the computational cost, the mechanical deformation and the flow and heat transfer models are solved separately and coupled sequentially.

\section{Model Setup}

A simulation domain of $3 \times 3 \times 0.1 \mathrm{~km}$. is modelled, and in this domain two sets of natural fractures are modelled with a spacing of 400 meters as shown in Figure 1. 


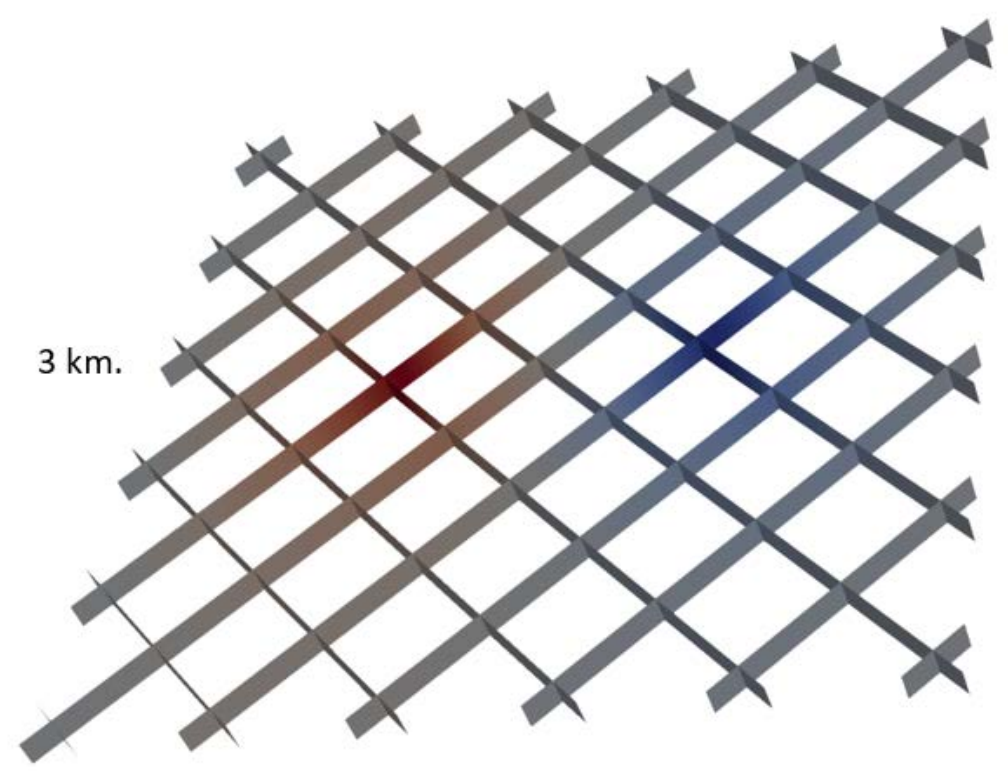

$3 \mathrm{~km}$.

Figure 1 Fracture network in the simulation domain.

In this simulation domain an injection well and a production well is placed 1,131 meters apart. The injection and production are simulated through constant injection pressure of $25 \mathrm{MPa}$, and production pressure of $5 \mathrm{MPa}$. The initial reservoir pressure is set to $15 \mathrm{MPa}$. Three cases are defined based on the location of the wells with respect to the fracture network:

1- Base case: wells are located in the center of matrix blocks and away from the fracture network

2- Mid case: wells are located in the matrix block, but closer to the fracture network (min distance is $47 \mathrm{~m}$ )

3- High case: wells are located at the intersection of the two fracture sets.

Table 1 lists some main parameters used in each of the three cases.

Table 1 Main parameters used in the simulations.

\begin{tabular}{|l|l|l|l|}
\hline Parameter & Base case & Mid case & High case \\
\hline Matrix permeability & $1 \mathrm{e}-15 \mathrm{~m}^{2}$ & $1 \mathrm{e}-15 \mathrm{~m}^{2}$ & $1 \mathrm{e}-15 \mathrm{~m}^{2}$ \\
\hline Fracture aperture & $1 \mathrm{e}-7 \mathrm{~m}$ & $5 \mathrm{e}-4 \mathrm{~m}$ & $5 \mathrm{e}-4 \mathrm{~m}$ \\
\hline Injection well pressure & $25 \mathrm{MPa}$ & $25 \mathrm{MPa}$ & $25 \mathrm{MPa}$ \\
\hline $\begin{array}{l}\text { Production well } \\
\text { pressure }\end{array}$ & $5 \mathrm{MPa}$ & $5 \mathrm{MPa}$ & $5 \mathrm{MPa}$ \\
\hline Well diameter & $0.10 \mathrm{~m}$ & $0.10 \mathrm{~m}$ & $0.10 \mathrm{~m}$ \\
\hline Laterals diameter & $0.04 \mathrm{~m}$ & $0.04 \mathrm{~m}$ & $0.04 \mathrm{~m}$ \\
\hline
\end{tabular}

\section{Validation}

The numerical model has been validated against several analytical and numerical examples. Here, the validation against the numerical results presented by Guo et al. (2016) is presented. In this example, the injection and production wells are located $500 \mathrm{~m}$ apart, and both wells intersect a horizontal circular fracture of diameter $1000 \mathrm{~m}$. The initial temperature is set at $200{ }^{\circ} \mathrm{C}$, while the cold water is injected at $50^{\circ} \mathrm{C}$. Cooling of the matrix alters the stress distribution in the matrix and that changes the aperture in the fracture. The Fracture aperture is model using the Barton-Bandi's model

$$
A=A_{\text {max }}-\frac{a \sigma_{n}^{\prime}}{1+b \sigma_{n}^{\prime}}
$$

where $\sigma_{n}^{\prime}$ is the effective stress, $A_{\max }$ is given as $0.0012 \mathrm{~m}$ and $a$ and $b$ are two constants, determined by two reference states for the effective stress, where the aperture is known. The first known state is $\sigma_{n}^{\prime}=30 \mathrm{MPa}$ and $A=0.00024 \mathrm{~m}$, and the second known state is $\sigma_{n}^{\prime}=5 \mathrm{MPa}$ and $A=0.00072 \mathrm{~m}$. 
With this the constants $a$ and $b$ are found to be $a=1.6 e-10$ and $b=1.3 e-7$. The results of the validation can be seen on Figure 2.

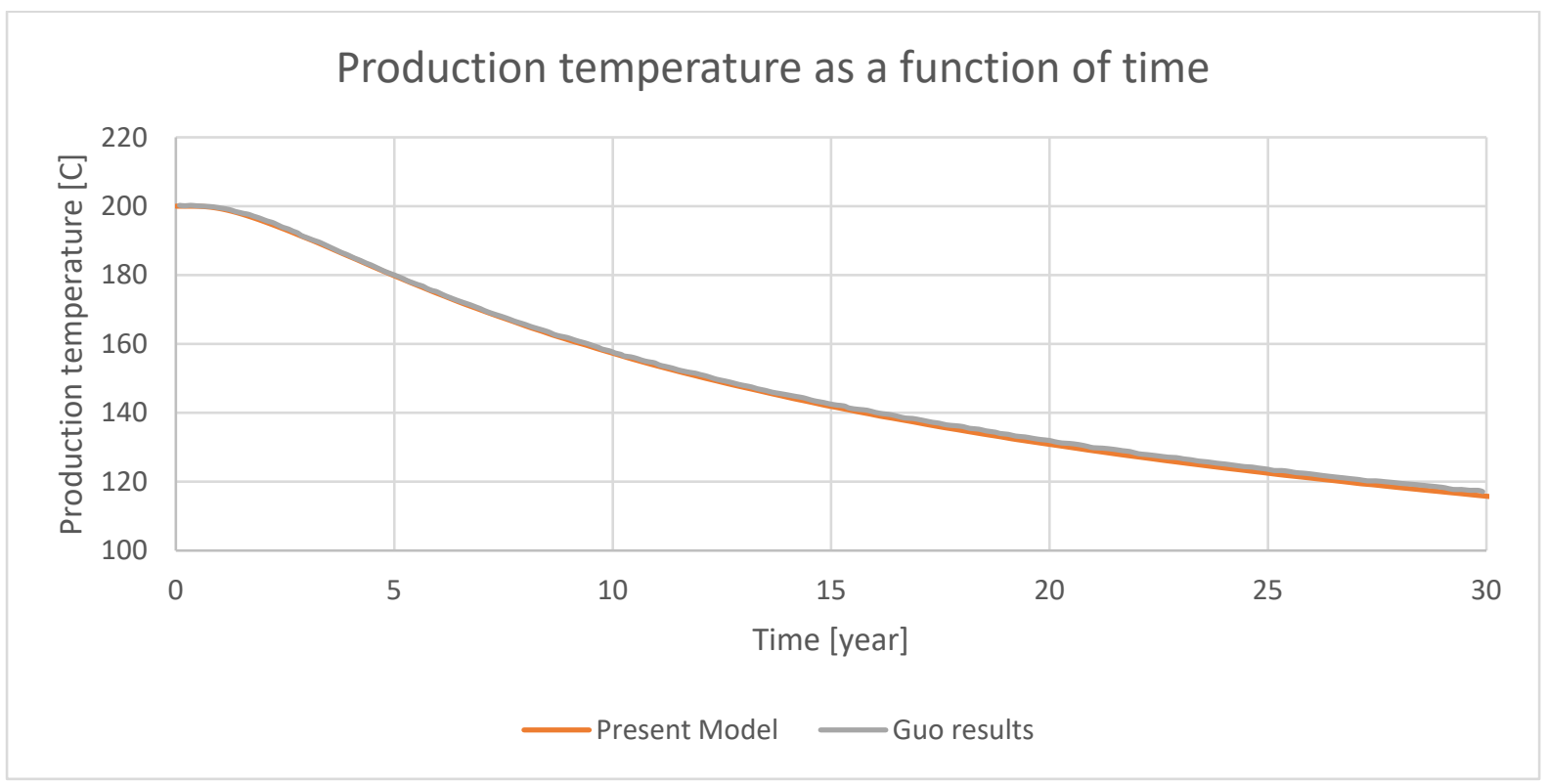

Figure 2 Simulation results for the present model, and results from (Guo et al., 2016).

This shows very good agreement between the results found by Guo et al. (2016) and the present model.

\section{Preliminary Results}

The well locations used to generate the three cases is shown in Figure 3. The spacing between the wells are kept constant at $1,131 \mathrm{~m}$, but they are moved relative to the fracture. The injection well is indicated with the red circle, and the production well is indicated with the blue circle.

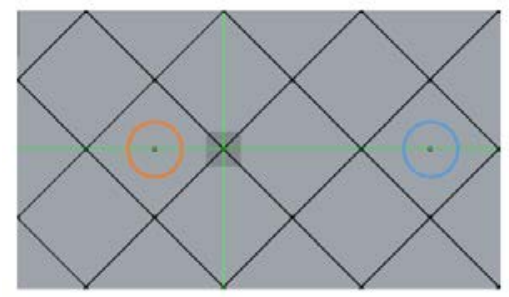

(a) - Base case

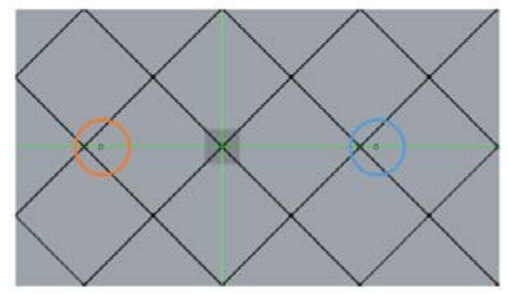

(b) - Mid case

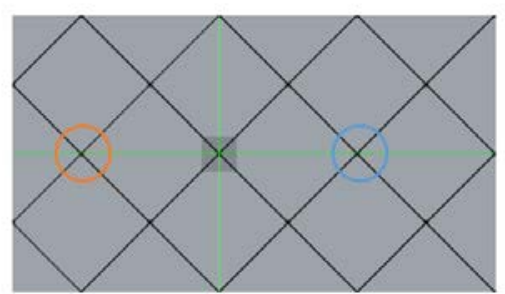

(c) - High case

Figure 3 (a) shows the well placements of the base case. (b) shows the placement of the mid case, and (c) shows the well placement of the high case. The blue circle indicates the production well and red circle indicates the injection well.

The steady-state flow rates of the production well for the three cases are listed in table 2 .

Table 2 Flowrate of the production well for each case.

\begin{tabular}{|l|l|}
\hline & Flowrate of production well \\
\hline Base case & 0.000771985 \\
\hline Mid case & 0.00106958 \\
\hline High case & 0.0597024 \\
\hline
\end{tabular}


The results show the importance of the connection of the wells to the fracture network in order to get the economical flow rates. RJD laterals can be used to connect the wells to the nearest fracture network. So, two more cases are simulated in which four horizontal laterals with a length of $50 \mathrm{~m}$ are drilled out from the wells. In one case, some of the laterals connect to the fracture network, while in the other case the RJD laterals fail to connect directly to the fracture network. When adding four laterals to both wells in a 90o degree pattern to the mid case, the flowrate of the production well is increased as given in Table 3.

Table 3 Improved flowrates for mid case with laterals.

\begin{tabular}{|l|l|}
\hline & Flowrate of production well \\
\hline Mid case (laterals not connected to fractures) & 0.00651557 \\
\hline Mid case (laterals connected to fractures) & 0.0638219 \\
\hline
\end{tabular}

\section{Conclusions}

A numerical model considering a doublet system consisting of an injection well and a production well in a fractured reservoir has been developed. The model has been validated against the results published by Guo et al. (2016).

The Preliminary results show that well placement is a very important factor when it come to the productivity of such a system. Connection to the natural fractures can significantly increase the flow rates. It is shown that RJD laterals can be utilize to improve the productivity of the doublet by connecting the wells to the nearest fracture network. Further investigation on the effect of different parameters including fracture aperture variation, fracture geometry, lateral geometry and lateral stability during production on the productivity enhancement will be performed within the present study.

\section{Acknowledgments}

The authors would like to thank the European Union for funding this work through European Union's Horizon 2020 research and innovation programme under grant agreement No 654662 .

\section{References}

Buset, P., Riiber, M., Eek, A. (2001). ”Jet Drilling Tool: Cost-Effective Lateral Drilling

Guo, B., Fu, P., Hao, Y., Peters, C., \& Carrigan, C. R. (2016). Thermal drawdown-induced flow channeling in a single fracture in EGS. Geothermics 61: 46-62.

Kamel, A.H. (2014). "RJD revitalizes mature Kansas oilfield”. Oil \& Gas Journal, 112(10).

Salimzadeh S., Nick H.M., Zimmerman R.W., 2018b. Thermoporoelastic effects during heat extraction from low permeability reservoirs, Energy, 142, 546-558.

Salimzadeh S., Paluszny A., Nick H.M. Zimmerman R.W., 2018a. A three-dimensional coupled thermos-hydro-mechanical model for deformable fractured geothermal systems, Geothermics, $71,212-224$. 